Eurasscience Journals

Eurasian Journal of Forest Science (2014) 2(2): 7-17

\title{
MODERN POLLEN DISTRIBUTION AT İĞNEADA WATERLOGGED FORESTS BETWEEN THE PERIODS SEPTEMBER 2007 - AUGUST 2009
}

\author{
Nurgül Karlığlu 1*, Hülya Caner 2, Ünal Akkemik ${ }^{1}$ \\ ${ }^{1}$ Department of Forest Botany, Faculty of Forestry, Istanbul University, 34473, Bahçeköy, Istanbul, Turkey, \\ nurgulk@istanbul.edu.tr*Corresponding author; nakkemik@istanbul.edu.tr \\ ${ }^{2}$ Institute of Marine Sciences and Management, Istanbul University, 34116 Vefa, Istanbul, Turkey, bcaner@istanbul.edu.tr
}

\begin{abstract}
Study has been worked to find out arboreal and non-arboreal pollen influx $\left(\mathrm{cm}^{2} / \mathrm{mo}\right)$ fallen to the ground and relations between striking meteorological parameters at Kirklareli-Iğneada waterlogged forests 6 plots between 2007-2009 where significantly high vegetation diversity was provided. Tauber style pollen traps have been installed into the 6 field plots and were replaced monthly. The pollen traps transferred to the laboratory Lycopodium spore tablets were used in accordance with European Pollen Monitoring Program and pollen slides were prepared. The annual pollen influx of Carpinus sp., Fraxinus sp., Hedera belix, Alnus sp., Corylus sp., Acer sp., and Quercus sp. was higher respectively between the period 2007 and 2009. Also, the annual pollen influx of Poaceae, Chenopodiaceae, Plantago sp., and Ambrosia sp. was higher respectively for the same period. Pollen influx increase significantly along open field conditions and forest canopy for herbaceous plant and arboreal plants respectively. Pollen density was lower at the period between 2008 and 2009 due to higher rain.
\end{abstract}

Keywords: İğneada waterlogged forest, Tauber style pollen trap, Lycopodium, pollen influx.

\section{Özet}

Çalışma, Kırklareli- İğneada Longoz Ormanları’nda vejetasyonun çeşitlilik gösterdiği 6 örnek alanda 2007-2009 yilları arasında toprağa düşen odunsu ve otsu bitki polen yoğunluğunu $\left(\mathrm{cm}^{2} /\right.$ ay) incelemek ve polen yoğunluğu değerlerinin önemli meteorolojik parametrelerle olan ilişkisini ortaya koymak amaciyla gerçekleştirilmiştir. Tauber tipi polen tuzakları bu 6 örnek alana yerleştirilmiş ve aylık olarak değiştirilmiştir. Araziden laboratuvara getirilen polen tuzaklarında Avrupa Polen İzleme Programı Protokolü'ne göre Lycopodium spor tabletler kullanılmış ve polen preparatları hazırlanmıştır. 2007-2009 yllına ait odunsu bitki (AP) polen yoğunluğu $\left(\mathrm{cm}^{2} / \mathrm{yll}\right)$ değişimlerine bakıldığında Carpinus sp., Fraxinus sp., Hedera belix, Alnus sp., Corylus sp., Acer sp., ve Quercus sp. türlerinin polen yoğunluklarının fazla olduğu tespit edilmiştir. Yine aynı yıllara ait otsu bitki (NAP) polen yoğunluğu $\left(\mathrm{cm}^{2} /\right.$ yll) değişimlerine bakıldığında Poaceae, Chenopodiaceae, Plantago sp., and Ambrosia sp. türlerine ait polen yoğunluklarının fazla olduğu görülmüştür. Açık alanda otsu bitki polen yoğunluğu artarken orman içine doğru gidildikçe odunsu bitki polen yoğunluğu artmaktadır. Yağışların yüksek olması nedeniyle, 2008-2009 dönemindeki polen yoğunluğu daha düşük çıkmışır.

Anahtar Kelimeler: İğneada Longoz Ormanı, Tauber tipi polen tuzağı, Lycopodium, polen yoğunluğu. 


\section{INTRODUCTION}

Modern pollen accumulation studies provide knowledge about annual pollen accumulation, relation between pollen accumulation and tree density and climatic variation. First pollen accumulation study has been conducted by Sheila Hicks in northern Finland to collect the data about long term pollen monitoring. Hicks (1994) realized that varying vegetation types were characterized by unique pollen accumulation rates (PAR) and she practiced the acquired data to give comment on fossil pollen diagram. Thus by using the data resulted by pollen monitoring experiments in INQUA (International Quaternary Research Union) research group in 1995 with the sediment carrots method pollen accumulation of Europe has been monitored and a new group named "Pollen Monitoring System (PMP)" has been established. Hicks (2001) emphasized that to configure the past vegetation structure by pollen analysis, plant density and vegetation distribution should have been determined. Hicks (2001) also made emphasize on requisite of understanding the relation between vegetation and pollen to re-configure some fossil pollen diagrams. Numeric data has been obtained by monitoring the pollen accumulation at varying vegetation points by Tauber pollen traps properly obeying to standard methods. In conjunction with establishment of Pollen Monitoring System many pollen monitoring stations were set in European countries. 28 pollen traps were placed at Picea, Pinus cembra, Larix and Alnus viridis forests in Alpine mountains by Van der Knaap et al. (2001) in 1991; 9 pollen traps were placed at Fagus, Abies and Pinus mixed forests in Roztocze National Park by Pidek (2004) in 1998, 2 pollen traps were placed at Pinus peuce, Pinus sylvestris, Picea and Fagus mixed forests in Rila mountains in Bulgaria by Tonkov et al. (2001) in 1993, 4 pollen traps were placed at Fraxinus, Ulmus and Carpinus mixed forests at Black Sea shores and 3 pollen traps were placed at Fagus orientalis and Quercus sp. mixed forests in Stranja mountains by Mariana Filipova-Marinova (Giesecke et al. 2010) in 2002.

Within the studies generally conducted in Europe while actual information could have been obtained about pollen distribution in one hand, on the other hand advantageous data could have been collected that would be helpful for explicating the pollen diagrams acquired from paleo-palynological studies. To know the relation between actual pollen density and actual vegetation is crucially helpful for estimating the forest density and mixture in the geological era. The palynological studies conducted in Turkey up to the present are mostly on pollen morphology, pollen analysis in varying environments (such as atmosphere, honey, coal, clay etc.) and pollen allergy. Among these studies actual pollen distribution takes an important portion and the mostly placed the Hirst Spore, Burkard and Lanzoni style traps to a certain height and from which they reached substantial results about pollen allergy. Thus pollen calendar has be able to been obtained belonged to many provinces of Turkey (Aytuğ et al., 1974; İnce and Pehlivan, 1990; Pehlivan and Bütev, 1994; İnceoğlu et al., 1994; Kaya and Aras, 2004; Bıçakç1, 2006; Öneş et al., 2008; Erkan et al., 2011). Among the actual pollen monitoring studies the initial monitoring pollen accumulation fallen on the soil in context of Pollen Monitoring System Protocol study was conducted by Karlioğlu and Akkemik (2012) in 2007 by placing 3 Tauber style trap in Istanbul University Research Forest. The current study conducted in İgneada Waterlogged forests again cohere the same protocol for monitoring the pollen distribution on a certain soil area $\left(\mathrm{cm}^{2} /\right.$ year). The aim of this study is to determine arboreal pollen (AP) $\left(\mathrm{cm}^{2} / \mathrm{mo}\right)$, herbaceous pollen density (NAP) $\left(\mathrm{cm}^{2} / \mathrm{mo}\right)$ and to put on the relations between the pollen fallen on the soil surface and monthly average temperature $\left({ }^{\circ} \mathrm{C}\right)$ and precipitation $(\mathrm{mm})$. Within the current initial pollen monitoring study Turkey has been joined to Europe Pollen Monitoring System.

\section{MATERIAL AND METHODS}

\section{Study Site}

İğneada town belongs to officially KırklareliDemirköy province locates downhill of Istranca mountains at $20 \mathrm{~km}$ distance to Bulgaria border line and has shore to Black sea. According to Davis' (19651985) grid system locates in A1 (E) square. The altitudinal profile of İğneada waterlogged forests varies between $0-20 \mathrm{~m}$ (Fig.1). Since the slope average is approximately $1-2 \%$ the study area might be perceived as a flat field. At the study area there are 6 lakes named Saka, Mert, Erikli, Deniz, Hamam and Pedina. Although those lakes are surrounded by reed plants western side of Saka, Erikli and Mert lakes construct waterlogged forests (Kavgac1 2007). 


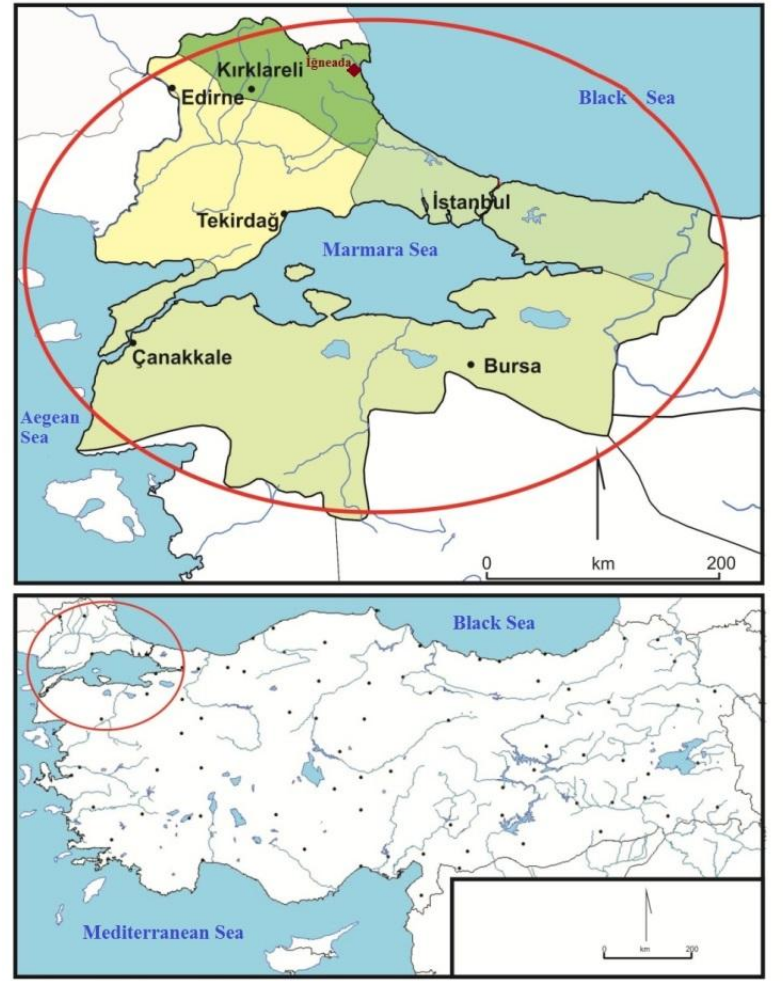

Figure 1. Geographical positions of study points (A: Istranca section, B: Çatalca-Kocaeli section, C: South Marmara Section, D: Ergene section).

İğneada waterlogged forests are accepted as one of the 122 Important Plant Areas of Turkey and has the vegetation types such as waterlogged forest, peat, bog and sand dunes plant communities and sandy meadows at river side banks, sand zone and wetlands (Özhatay et al 2005). The main species composition of waterlogged forests is composed from the species of Fraxinus ornus L., Alnus glutinosa L., Ulmus campestris L. and Salix sp. (willow). Besides Acer campestre L., Corylus avellana L., Populus tremula L., Carpinus orientalis Miller., Fagus orientalis Lipsky, Ulmus leavis Pallas and various Quercus sp. species also join to the forest tree species mixture. The species Prunus spinosa L., Rubus fruticosus L., Corylus avellana L., Acer pseudoplatanus L., Crataegus monogyna Jacq., Sorbus torminalis (L.) Crantz., Sambucus nigra L., Hedera helix L., Smilax excelsa L. and Dryopteris constitute the canopy structure of the forest (Dönmez, 1968). Kavgac1 (2007) determined 6 vegetation types such as waterlogged forests with Fraxinus angustifolia, Alnus glutinosa, Quercus robur L. and Carpinus betulus L. species, high forests with Quercus frainetto Ten, Q. petraea (Mattuschka) Liebl., Q. cerris L., Carpinus orientalis Miller and Fraxinus ornus L. species, lake, bog, shrub species and sand dunes. Meteorological station of İğneada does not exist at the study area. Kumköy meteorological station which is $100 \mathrm{~km}$ air distance far to study area assumed to be most representative for data obtain. Water balance has been presented in figure 2 calculated according to Thornthwaite method with the data set collected between 1963-2005 years. According to the stated climatic data the average annual temperature is $13.8^{\circ} \mathrm{C}$, coldest months January and February, hottest month is August, average annual precipitation is 793 $\mathrm{mm}$. According to Thornthwaite water balance the area has semi-humid, second order mezzo-thermal, efficient water deficient in summer and close to oceanic climatic properties which can be formulated as $\mathrm{C}_{2} \mathrm{~B}_{2}^{\prime} \mathrm{s}^{2} \mathrm{~b}_{4}^{\prime}$. The water deficiency is compensated by water table which generally raises in waterlogged forests (Pamay 1967, Fig. 2).

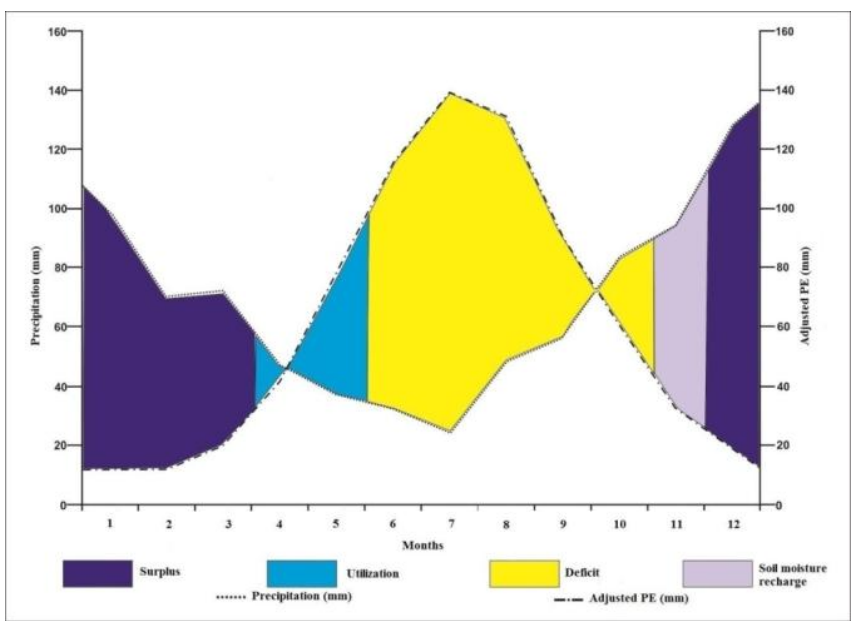

Figure 2. Water balance graphic of Kumköy meteorological station produced according to Thornthwaite method.

Tecimen and Kavgac1 (2010) made a research to determine the soil properties of waterlogged forests where they sampled 48 plots which are distributed to waterlogged forest, thermophile forest and sand dunes. The least sandy soils with the content rate of $52.4 \%$ are at waterlogged forest and 64 and $91 \%$ thermophile forest and sand dune respectively. 


\section{Establishment of pollen traps}

Along the study 6 Tauber style pollen traps (Tauber, 1974; Hicks ve Hyvarinen, 1986) were initially located to open field, near the forest and in the forest where the vegetation type differed significantly (Fig. 3, Table 1). The code, coordination, altitude and the description of surrounding vegetation of the trap points were given in table 1 . Pollen traps were collected monthly during 24 months from September 2007 to August 2009 that covers two vegetation periods.

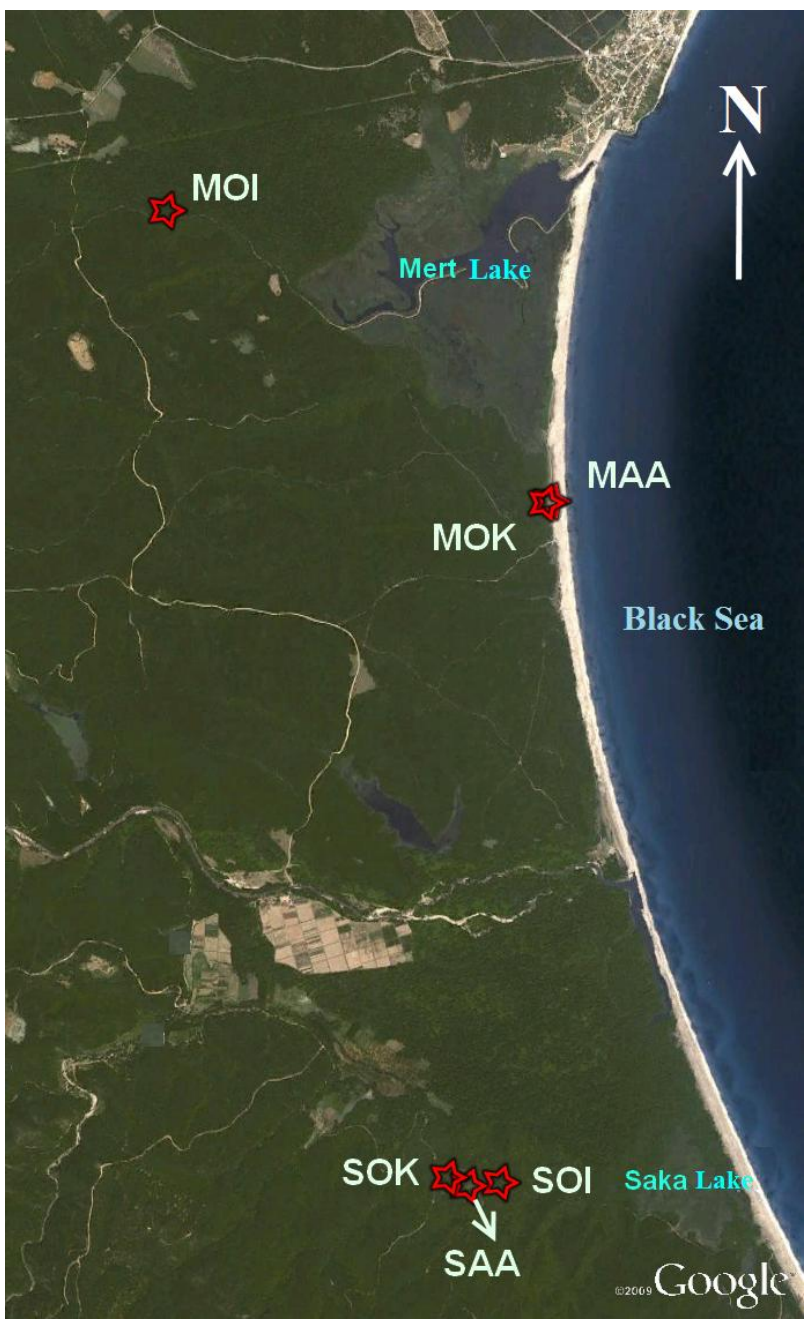

Figure 3. Positions of 6 Tauber style pollen traps on the satellite photograph. MOI: Mert Lake waterlogged forest inner forestland, MOK: Mert Lake waterlogged forest - near forestland, MAA: Mert lake waterlogged forest - open field, SOI: Saka lake waterlogged forest - inner forestland, SOK: Saka lake waterlogged forest - near forestland, SAA: Saka lake waterlogged forest - open field.
Due to European Pollen Monitoring System Protocol (Hicks et al 1996), top hole width should be 5 $\mathrm{cm}$ and base width $15 \mathrm{~cm}$. The closing top has a smooth slope to prevent rain water penetration (Fig. 4).
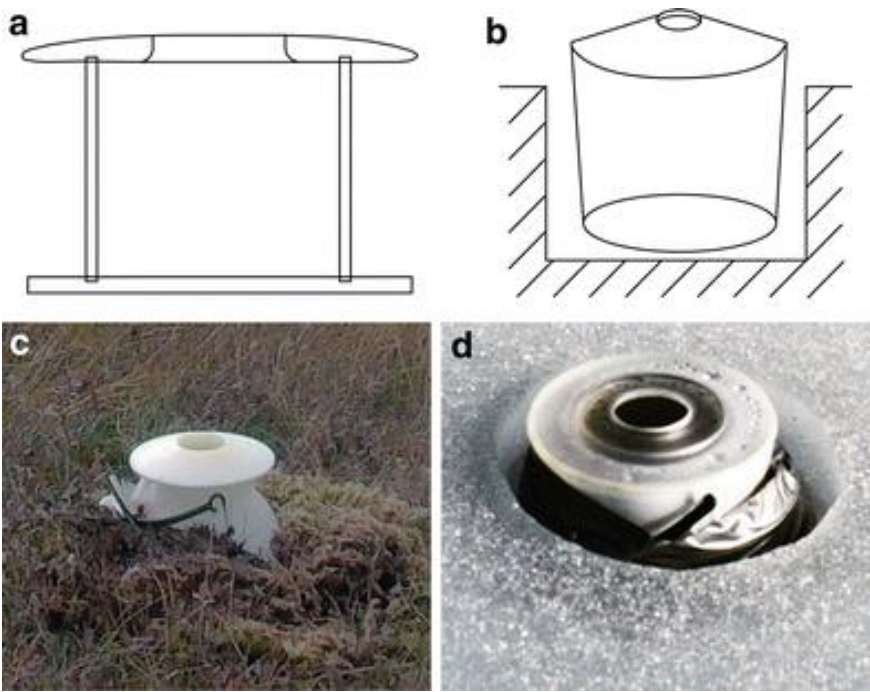

Figure 4. Varying designs of pollen traps created by Tauber (1974) (Giesecke et al 2010).

The mixture for pollen accumulation has monthly been added to the traps. The mixture is formed from glycerin, formalin and thymol. While the glycerin provides the fixation of pollen in the trap, thymol and formalin takes role of inhibition of bacteria and fungi activity. Glycerin has been applied to form a 3-5 $\mathrm{mm}$ thickness at the bottom of the trap and cover the entire bottom. Formalin has been added 10-20 ml and thymol $4 \mathrm{~g}$ (Hicks et al 1996).

\section{Description of vegetation type around pollen traps}

In accordance with the method described by Hicks et al (1996) the herbal and woody plants coincided in the surrounding circle with the radius $10.5 \mathrm{~m}$ were diagnosed and recorded to the vegetation table (Table 2). "Flora of Turkey and The East Aegean Islands" has been used as the main reference to name the herbal and woody plants (Davis, 1965-1985; Davis et al, 1988; Güner et al, 2000). The $10 \mathrm{~m}$ to $2 \mathrm{~km}$ far surrounding vegetation type of pollen traps were made by stand maps. 
Table 1. The code, coordination, altitude and the description of surrounding vegetation of the trap points.

\begin{tabular}{|c|c|c|c|c|}
\hline Pollen trap code & Coordinates & Altitude & Vegetation & Description of vegetation and and closure \\
\hline MAA & $\begin{array}{l}41^{\circ} 50^{\prime} 48.8^{\prime \prime} \mathrm{N} \\
27^{\circ} 58^{\prime} 39.4^{\prime \prime} \mathrm{E}\end{array}$ & $4 \mathrm{~m}$ & $\begin{array}{c}\text { Anemone pavonina, } \\
\text { Muscari neglectum, } \\
\text { Pancratium maritimum, } \\
\text { Cionura erecta } \\
\end{array}$ & Sand dune plants \\
\hline MOK & $\begin{array}{l}41^{\circ} 50^{\prime} 48.3^{\prime \prime} \mathrm{N} \\
27^{\circ} 58^{\prime} 37.8^{\prime \prime} \mathrm{E}\end{array}$ & $5 \mathrm{~m}$ & $\begin{array}{c}\text { Acer campestre, Crataegus monogyna, } \\
\text { Fraxinus angustifolia, Prunus } x \text { domestica } \\
\text { Rosa canina, Rubus sanctus, } \\
\text { Ruscus aculeatus, Ulmus minör }\end{array}$ & Forest, $60 \%$ \\
\hline MOI & $\begin{array}{l}41^{\circ} 51^{\prime} 59.5^{\prime \prime} \mathrm{N} \\
27^{\circ} 56^{\prime} 34.7^{\prime \prime} \mathrm{E}\end{array}$ & $11 \mathrm{~m}$ & $\begin{array}{l}\text { Acer campestre, Carpinus betulus, } \\
\text { Corylus avellana, Fagus orientalis, } \\
\text { Fraxinus angustifolia, Rubus sanctus, } \\
\text { Ruscus aculeatus, Tilia argentea }\end{array}$ & Forest, $90 \%$ \\
\hline SAA & $\begin{array}{l}41^{\circ} 48^{\prime} 03.7^{\prime \prime} \mathrm{N} \\
27^{\circ} 58^{\prime} 13.5^{\prime \prime} \mathrm{E} \\
\end{array}$ & $32 \mathrm{~m}$ & $\begin{array}{c}\text { Fraxinus angustifolia, Pyrus elaeagnifolia, } \\
\text { Rosa canina }\end{array}$ & - \\
\hline SOK & $\begin{array}{l}41^{\circ} 48^{\prime} 05.9^{\prime \prime} \mathrm{N} \\
27^{\circ} 58^{\prime} 07.0^{\prime \prime} \mathrm{E}\end{array}$ & $42 \mathrm{~m}$ & $\begin{array}{l}\text { Acer campestre, Crataegus monogyna, } \\
\text { Fraxinus angustifolia, Malus sylvestris, } \\
\text { Quercus robur Ulmus minor }\end{array}$ & Forest, $70 \%$ \\
\hline SOI & $\begin{array}{l}41^{\circ} 48^{\prime} 04.1^{\prime \prime} \mathrm{N} \\
27^{\circ} 58^{\prime} 23.7^{\prime \prime} \mathrm{E}\end{array}$ & $22 \mathrm{~m}$ & $\begin{array}{l}\text { Acer campestre Carpinus orientalis, } \\
\text { Cornus mas, Corylus avellana, } \\
\text { Fraxinus angustifolia, } \\
\text { Quercus robur, Ruscus aculeatus }\end{array}$ & Forest, $80 \%$ \\
\hline
\end{tabular}

\section{Installation of pollen slides and analysis}

Pollen slides were prepared in accordance with Europe Pollen Monitoring System Protocol by using Lycopodium tablets (Stockmarr 1971) and were counted. The least arboreal pollen number is 200 and Lycopodium spore number is 50 has been provided (www.pollentrapping.net).

Prior to slide preparation the mixture obtained from pollen traps were filtered with $250 \mu \mathrm{m}$ filter and animal and plant detritus were removed and subjected to chemical analysis. Each mixture obtained from pollen traps were added 2 Lycopodium spore tablet, 10 $\mathrm{ml}$ distilled water and $0.5 \mathrm{ml} \mathrm{HCl}$ and centrifuged (10 minutes at 3000-3500 rpm). Following centrifuging acetolysis has been applied. After acetolysis pollen slides were prepared with addition of $2 \mathrm{ml}$ glycerin. Each slide has been noted of collection date and sampling plot.

Pollen and Lycopodium grains were counted by Leica DM 750 trademark light microscope with $\mathrm{x} 40$ and x100 immersion objective and x10 ocular. For the diagnosis of pollens reference pollen slides in Istanbul University Palynology Laboratory and pollen maps
(Aytuğ, 1967; Aytuğ et al., 1971; Wodehouse, 1935; Erdtman, 1952; 1957; Hyde and Adams, 1958; Faegri and Iversen, 1964; Moore et al., 1991; Hesse et al., 2009; Iwanami et al., 1988). Pollens were diagnosed at family and genus level and density fell on soil surface ( $\mathrm{cm} 2 / \mathrm{mo})$ were calculated according to Europe Pollen Monitoring Protocol and pollen diagrams were drawn.

\section{RESULTS}

\section{Pollen density and the plant cover around the pollen trap}

Although absences of Alnus, Carpinus and Corylus around pollen trap in the $10.5 \mathrm{~m}$ radius circle at Mert Lake waterlogged forest open field and forest edge, their pollen grains carried by wind were detected highly in years 2007-2009. Also, the pollen grains of Pinus nigra and Cedrus disperse by the wind over long distances $(2.5-3 \mathrm{~km})$ thanks to their air sacs, and thus their pollen influx found more than the other woody plants at Saka Lake waterlogged forest open field point during two years. 
Table 2. The herbal and woody plants coincided in the pollen trap surrounding circle with the radius $10.5 \mathrm{~m}$ at Mert and Saka lake waterlogged forests

\begin{tabular}{|c|c|}
\hline & Plant species \\
\hline $\begin{array}{l}\text { Open area } \\
\text { (MAA) }\end{array}$ & $\begin{array}{l}\text { Acer campestre, Anagallis sp., Anchusa azurea, Anthemis } \\
\text { tinctoria, Asparagus acutifolius, Aster sp., Cionura erecta, } \\
\text { Conium maculatum, Crambe maritima, Crataegus } \\
\text { monogyna, Dactylis glomerata, Eryngium maritimum, } \\
\text { Fraxinus angustifolia, Geranium sp., Hordeum sp., Juncus } \\
\text { beldreichianus, Matricaria chamomilla, Matthiola fruticulosa, } \\
\text { Medicago sp., Medicago marina, Muscari sp., Plantago lanceolata, } \\
\text { Poa sp., Potentilla sp., Prunus x domestica, Rubus } \\
\text { sanctus, Salvia, sp., Sideritis montana, Silene dichotoma, Silene } \\
\text { sangaria, Silene vulgaris, Taraxacum sp., Teucrium polium, } \\
\text { Tragopogon sp., Trifolium repens, Ulmus minor, Verbascum } \\
\text { sp., Vicia cracca. }\end{array}$ \\
\hline $\begin{array}{l}\text { Forest } \\
\text { edge } \\
(\mathrm{MOK})\end{array}$ & $\begin{array}{l}\text { Acer campestre, Allium sp., Ajuga reptans, Anchusa aqurea, } \\
\text { Apiaceae, Asparagus acutifolius, Bellis perennis, Crataegus } \\
\text { monogyna, Eryngium maritimum, Fraxinus angustifolia, } \\
\text { Galium odoratum, Geranium sp., Geum urbanum, Hedera } \\
\text { helix, Lolium sp., Medicago sp., Ophrys oestifera, Plantago } \\
\text { lanceolata, Poa sp., Poaceae, Prunus x domestica, } \\
\text { Ranunculus sp., Rosa canina, Rubus sanctus, Ruscus } \\
\text { aculeatus, Salvia sp., Silene sp., Smilax excelsa, Trifolium } \\
\text { sp., Ulmus minor, Verbascum, Vitis sp. }\end{array}$ \\
\hline $\begin{array}{l}\text { Forest } \\
\text { (MOI) }\end{array}$ & $\begin{array}{l}\text { Acer campestre, Carpinus betulus, Corylus avellana, } \\
\text { Cyperaceae, Fagus orientalis, Fraxinus angustifolia, } \\
\text { Geum urbanum, Hedera helix, Poa sp., Polygonatum } \\
\text { multiflorum, Ranunculus sp., Rubus sanctus, Ruscus } \\
\text { aculeatus, Smilax excelsa, Sorbus torminalis, Tilia } \\
\text { argentea, Urtica dioica, Valerianaceae, Viola odorata. }\end{array}$ \\
\hline $\begin{array}{l}\text { Open area } \\
\text { (SAA) }\end{array}$ & $\begin{array}{l}\text { Asteraceae, Bromus sp., Fraxinus angustifolia, Geum sp., } \\
\text { Juncus heldreichianus, Lolium sp., Medicago sp., Mentha sp., } \\
\text { Oenanthe sp., Plantago lanceolata, Plantago major, Poaceae, } \\
\text { Pyrus elaeagnifolia, Rosa canina, Taraxacum sp., } \\
\text { Trifolium sp. }\end{array}$ \\
\hline $\begin{array}{l}\text { Forest } \\
\text { edge } \\
\text { (SOK) }\end{array}$ & $\begin{array}{l}\text { Acer campestre, Ajuga reptans, Apiaceae, Crataegus } \\
\text { monogyna, Dactylis glomerata, Fraxinus angustifolia, } \\
\text { Fumaria sp., Galium sp., Geranium sp., Hedera helix, } \\
\text { Liliaceae, Malus sylvestris, Medicago sp., Oenanthe sp., } \\
\text { Orabanche sp., Poaceae, Quercus robur, Ranunculus sp., } \\
\text { Rosa canina, Ruscus aculeatus, Smilax excelsa, } \\
\text { Trifolium sp., Ulmus minor, Viola odorata. }\end{array}$ \\
\hline $\begin{array}{l}\text { Forest } \\
\text { (SOI) }\end{array}$ & $\begin{array}{l}\text { Acer campestre, Carpinus orientalis, Cornus mas, } \\
\text { Corylus avellana, Crataegus monogyna, Crepis sp., } \\
\text { Fraxinus angustifolia, Fumaria sp., Galium sp., Geranium } \\
\text { sp., Geum sp., Hedera helix, Neottia nidus-avis, Polygonatum } \\
\text { multiflorum, Quercus robur, Ranunculus sp., Ruscus } \\
\text { aculeatus, Ruscus bypoglossum, Smilax excelsa, Viola } \\
\text { odorata. }\end{array}$ \\
\hline
\end{tabular}

Pollen influx results obtained from Mert Lake waterlogged forest belong to years 2007-2008 and 2008-2009

Herbaceous pollen influx at Mert Lake waterlogged forest open field point between years 2007-2008 is higher than the woody plant pollens. Comparing to the generally collected woody plant pollens of Carpinus and Acer species and herbaceous pollens of Cyperaceae, Apiaceae, Asteraceae and Poaceae were remarkably higher respectively. Arboreal pollen influx is higher than non-arboreal pollen influx in the forest edge and forest point. The most arboreal pollen influx was belong to Carpinus, Hedera belix, Crataegus, Corylus, Fraxinus and Acer species in these sample points and herbaceous pollens of Poaceae, Plantago and Ambrosia were remarkably higher respectively (Figure 5). In the years of 2008-2009, the annual pollen influx of Fraxinus, Alnus, Hedera helix and Carpinus and herbaceous pollens of Cyperaceae, Juncus, Ambrosia, and Poaceae were remarkably higher respectively in three sample point of Mert Lake waterlogged forest (Figure 5).

Pollen influx results obtained from Saka Lake waterlogged forest belong to years 2007-2008 and 2008-2009

Arboreal pollen influx at Saka Lake waterlogged forest between years 2007-2008 is generally higher than the herbaceous pollen influx except open point. The most arboreal pollen influx was collected from Fraxinus, Crataegus, Acer, Carpinus, Quercus, Corylus, Hedera helix and Alnus in all sample areas. Also, herbaceous pollens of Poaceae, Plantago, Apiaceae and Ambrosia were remarkably higher respectively in this year (Figure 6). In the years of 20082009, the annual pollen influx of Fraxinus, Alnus, Hedera belix, Acer, Corylus, Alnus and Quercus and herbaceous pollen influx of Poaceae and Ambrosia were higher in all sample points of Saka Lake waterlogged forest (Figure 6).

Differentiation of pollen influx in relation with monthly temperature and precipitation

The most efficient meteorological parameters on pollen influx are temperature and precipitation. The relation between total monthly precipitation, monthly minimum, average and maximum temperature data and pollen influx were compared with the data obtained from Kumköy meteorological station since its location is similar to our study site. The comparisons were made for the most notable woody plant species (Carpinus, Fraxinus and Alnus) growing in waterlogged forests.

One of the main tree species constituting Mert and Saka waterlogged forests is Carpinus genus. The density of pollen distribution of Carpinus is remarkably higher between 2007-08 year periods than 2008-09 at all sampling points. Male flower pollens could not have been scattered because of high rain during February and March in 2009 (Figure 7-8). 


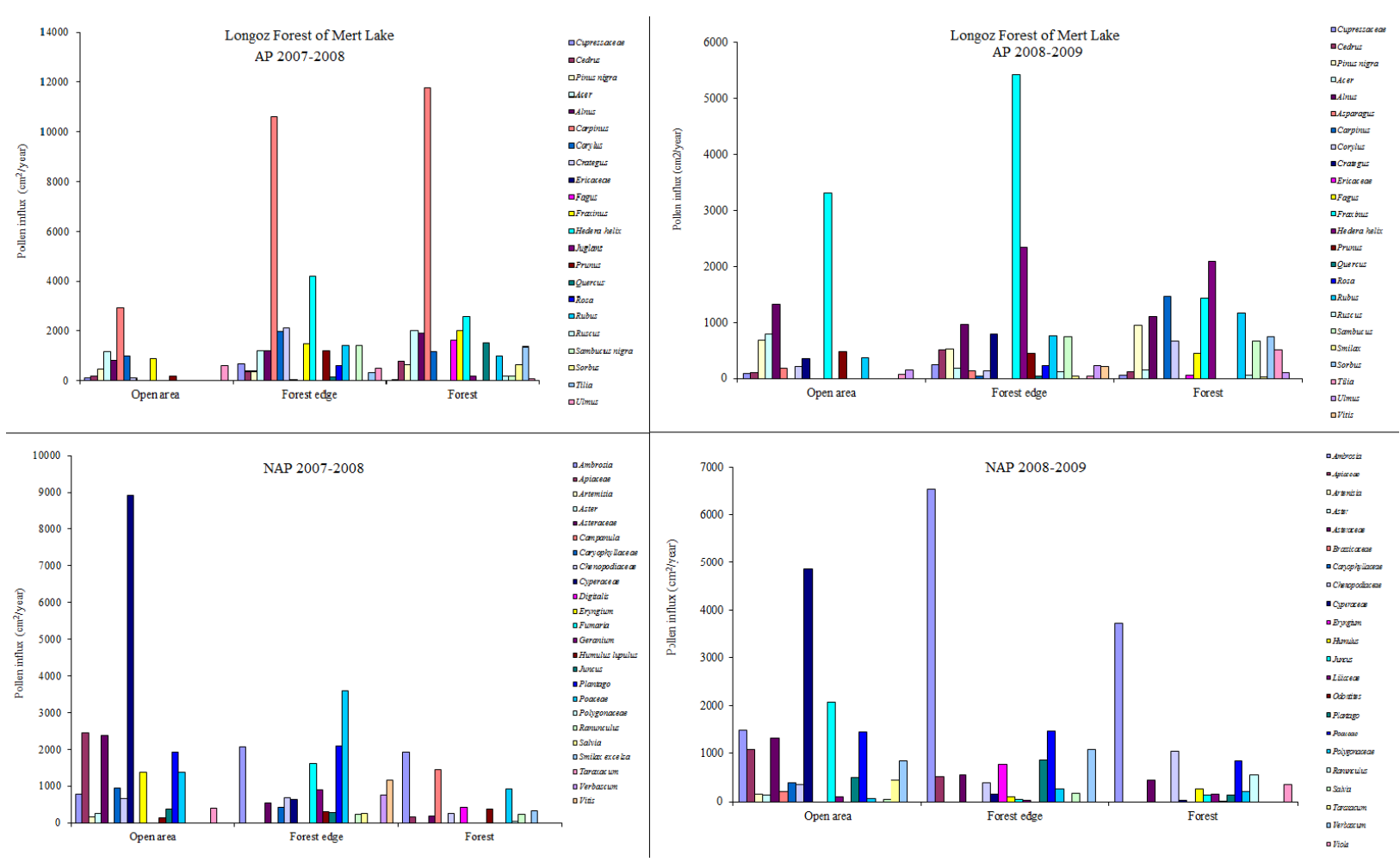

Figure 5. The pollen influx values during 2 years (2007-2009) in each sample area $\left(\mathrm{cm}^{2} /\right.$ year) of Mert lake waterlogged forest.
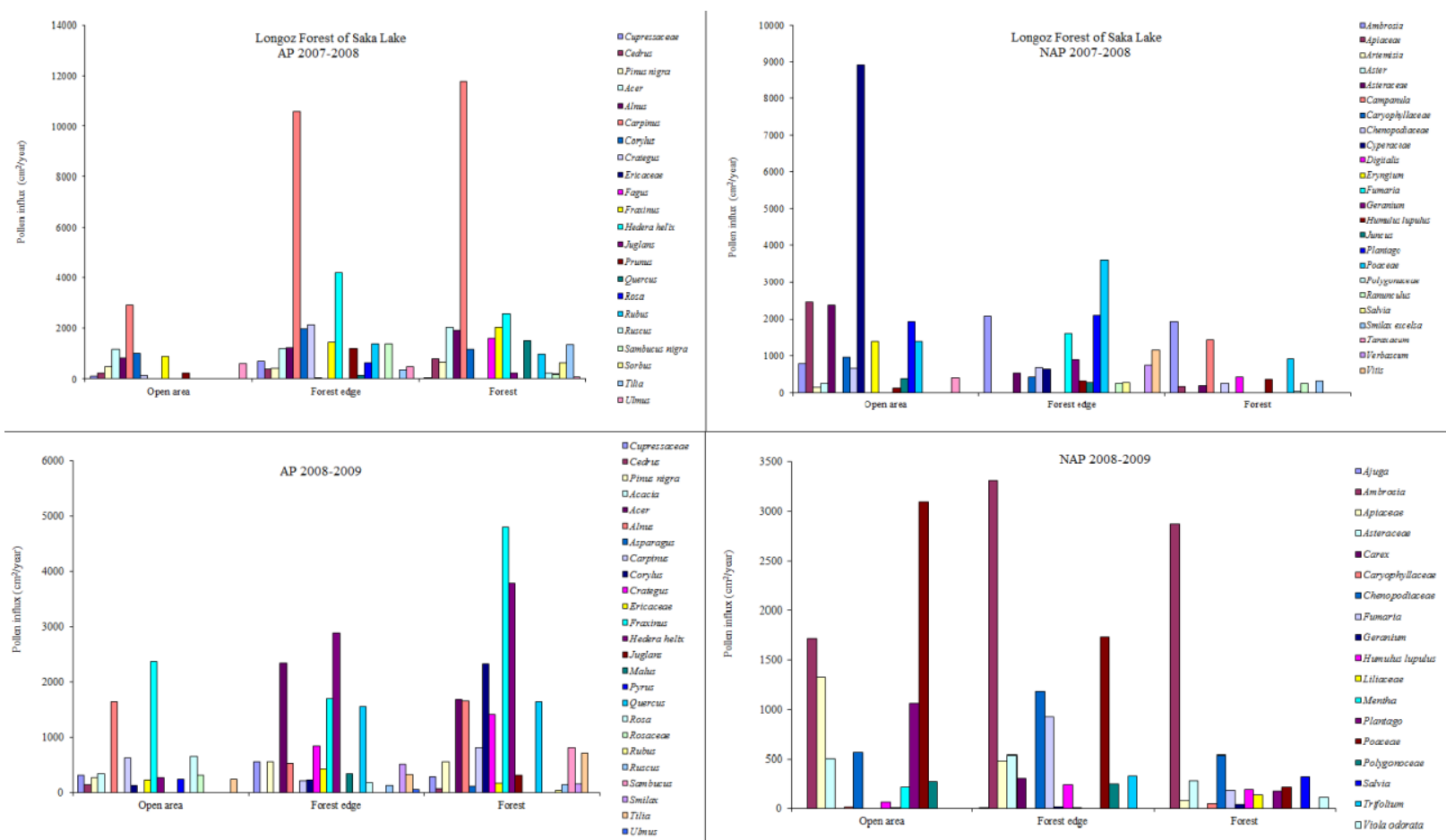

Figure 6. The pollen influx values during 2 years (2007-2009) in each sample area $\left(\mathrm{cm}^{2} /\right.$ year) of Saka lake waterlogged forest 


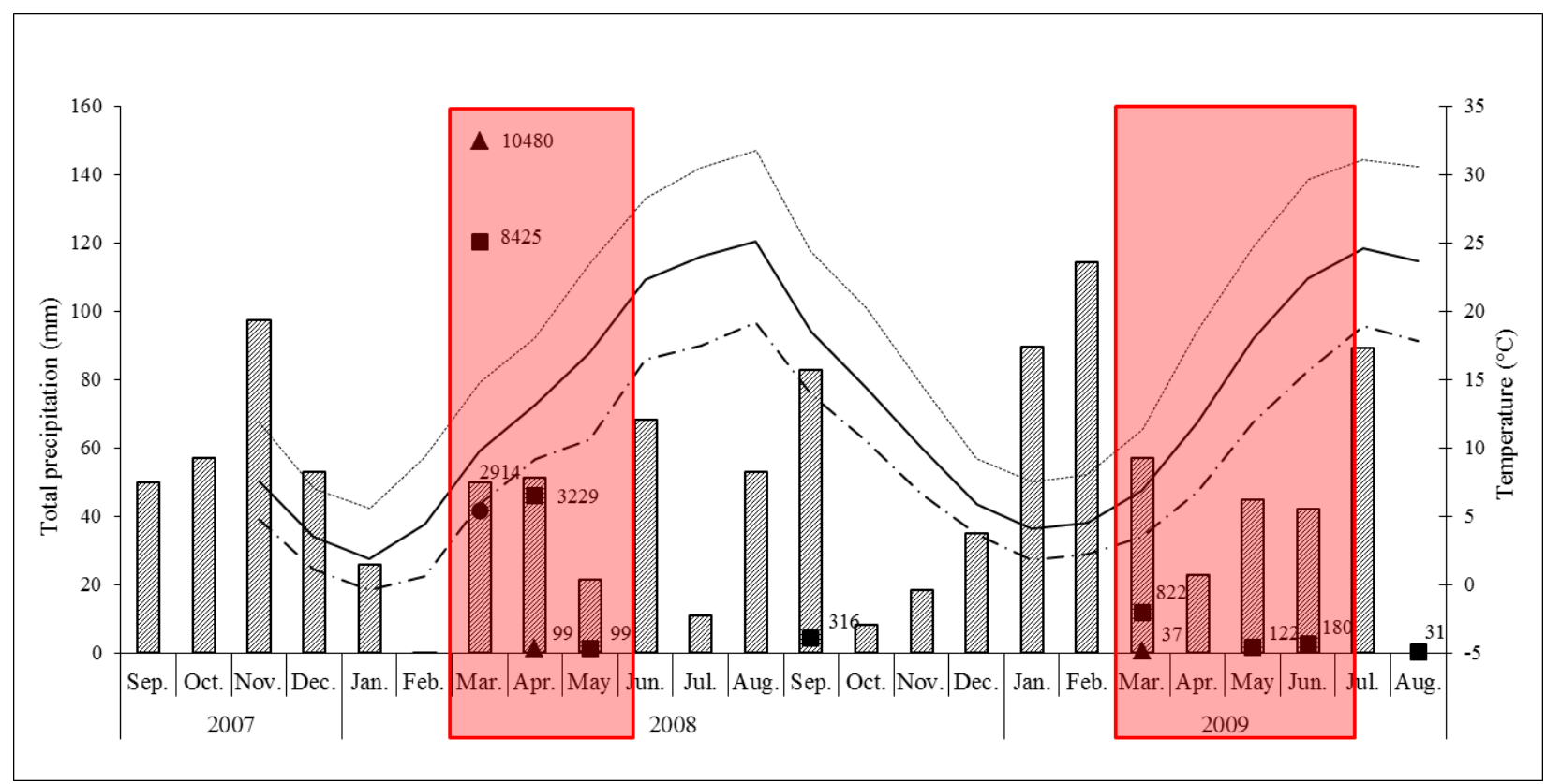

Figure 7. The relationship between monthly pollen influx of Carpinus and the meteorological parameters in the 3 different sample areas of Mert lake waterlogged forest from 2007 to 2009 (•, Open area; $\boldsymbol{\Delta}$, Forest edge; $\mathbf{\square}$, Forest).

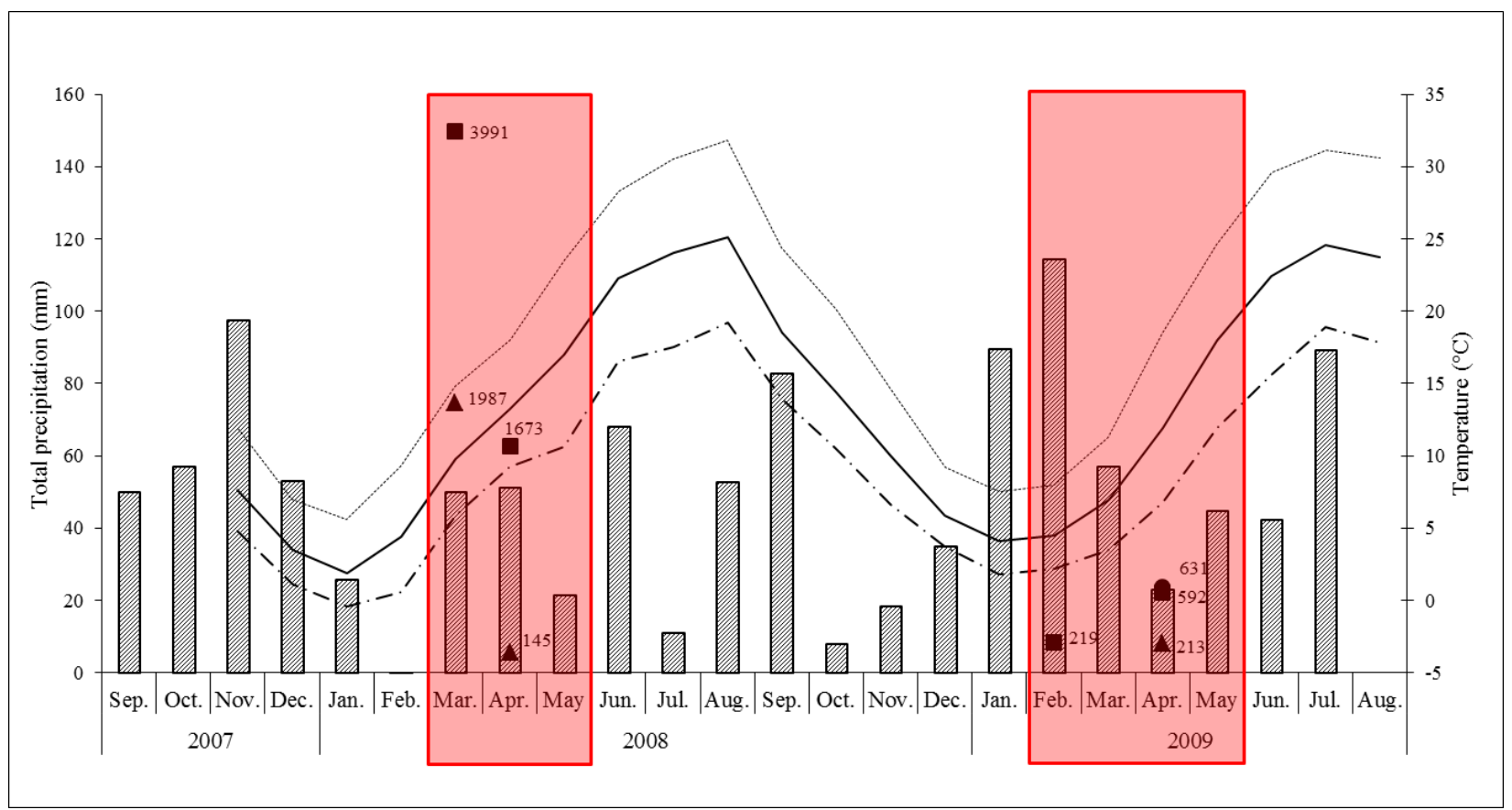

Figure 8. The relationship between monthly pollen influx of Carpinus and the meteorological parameters in the 3 different sample areas of Saka lake waterlogged forest from 2007 to 2009 (•, Open area; $\mathbf{\Delta}$, Forest edge; $\mathbf{n}$, Forest) 
The secondarily highly distributed tree species is Fraxinus genus. The density of pollen distribution of Fraxinus is remarkably higher between 2008-09 year periods than 2007-08 at all sampling points except Saka lake waterlogged forest. Fraxinus genus begins its pollen spreading in January and February. Pollen distribution of Fraxinus genus also presents a high density in February of 2009 at Mert Lake waterlogged forest. Male flower pollens of Fraxinus have accumulated in traps together with rain. Increased temperature and decreased rain in February of 2007-08 monthly pollen density of Fraxinus has increased.

The genus Alnus took the third place at forest tree species distribution. The density of pollen distribution of Alnus is remarkably higher between 2007-08 year periods than 2008-09 at all sampling points. Increased temperature and decreased rain in February of 2007-08 at Mert and Saka Lake waterlogged forests monthly pollen density of Alnus has increased. Although high rain in February of 2009 pollen distribution was highly accumulated in pollen traps.

\section{DISCUSSION AND CONCLUSION}

From the point of whole studied data view we reach to the result that Acer, Fraxinus, Alnus, Carpinus, Quercus, Corylus and Hedera belix are the highest pollen scattered species at Mert and Saka Lake waterlogged forests between the periods 2007-09. The herbaceous plants scattered the highest pollen are Poaceae, Chenopodiaceae, Plantago and Ambrosia. The woody species pollen amount decreased from the forest to open area gradient and vice versa herbaceous plant species. The pollen distribution reached to soil surface $\left(\mathrm{cm}^{2} /\right.$ year) is higher in 2007-08 compared to the next year period. That is caused from the high precipitation at the initial period of 2008-09 vegetation seasons.

The species especially having air sacs in their pollen grains like Pinus nigra have the potential to carry pollens long distance. Similarly Carpinus, Corylus and Alnus species can carry their pollens to distances changing between $10 \mathrm{~m}$ to $2 \mathrm{~km}$. Since the rest of deciduous species do not bloom the pollens of Alnus could be carried far distances by the wind (Pidek 2007). Although there was not Alnus species individuals around the pollen traps we detected pollens of Alnus species at all traps observed. Suszka (1980) found that Alnus pollens could have been carried approximately $200 \mathrm{~km}$ far from the source.
Alnus pollens could be carried to far distances since their weight is low. Betula and Pinus pollens can also be carried to far distances (Eisenhut, 1961; Andersen, 1970; Sugita et al., 1999; Broström, 2002). Within this study we found that Corylus and Pinus nigra pollens together with Alnus pollens could be carried to far distance. Among the tree species observed by European Pollen Monitoring System (for 9-10 year period) Alnus and Fagus have been mentioned to be the most important woody species (Pidek 2007; Pidek et al. 2010). The results obtained from this study constitute the first steps of pollen accumulation monitoring studies in İgneada waterlogged forests.

\section{Acknowledgements}

This paper is a part of Nurgül Karlıoğlu's PhD Thesis, and supported by the Research Fund of Istanbul University Project number:T-95/15122006, and Scientific and Technical Research Council of Turkey Project number: 1080856. We would like to thank both supporters.

\section{References}

Andersen, S.T. (1970). The relative pollen productivity and pollen representation of North European trees, and correction factors for tree pollen spectra, Danmarks Geologiske Undersogelse. II. Roekke, 96: 1-96.

Aytuğ, B. (1967). Polen Morfolojisi ve Türkiyenin Önemli Gymnospermleri Üzerinde Palinolojik Araştırmalar. Kutulmuş Matbaası, İstanbul.

Aytuğ, B., Aykut, S., Merev, N., Edis, G. (1971). İstanbul çevresi bitkilerinin polen atlası. İ.Ü. Orman Fakültesi Yayınları No:174, Kutulmuş Matbaası, İstanbul.

Aytuğ, B., Aykut, S., Merev, N., Edis, G. (1974). Belgrad Ormanı'nın ve İstanbul çevresi bitkilerinin polinizasyon olayının tespiti ve değerlendirilmesi. TÜBİTAK Yayınlar1 No:221.

Bıçakç1, A. (2006). Analysis of airborne pollen fall in SakaryaTurkey. Biologia. 61(4): 531-549.

Broström, A. (2002). Estimating source area of pollen and pollen productivity in the cultural landscapes of southern Sweden-developing a palynological tool for quantifying past plant cover. LUNDQUA Thesis 46, Lund University.

Davis, P. H. (1965-1985). Flora of Turkey and the East Aegean Islands. Vol. 1-9, Edinburg Univ. Press, Edinburg. 
Davis, P. H., Mill, R.R., Tan, K. (1988). Flora of Turkey and the East Aegean Islands. Vol. 10, Supplement, at the University Press, Edinburgh.

Dönmez, Y. (1968). Trakya'nın Bitkei Coğrafyası, İ.Ü. Coğrafya Enstitüsü Yayınları, No:51, İstanbul.

Eisenhut, G. (1961). Untersuchungen über die Morphologie und Ökologie der Pollenkörner heimischer und fremlandischer Wladbaume (translated into English by Jackson S.T. and Juamann P. 1989). Hamburg, Paul Parey.

Erdtman, G. (1952). Pollen Morphology and Plant Taxonomy- Angiosperms. The Chronica Botanica Company, Waltham, Mass., U.S.A.

Erdtman, G. (1957). Pollen and Spore Morphology / Plant Taxonomy - Gymnospermae, Pteridopybta, Bryophyta. Stockholm.

Erkan, P., Bıçakcı, A., Aybeke, M., Malyer, H. (2011). Analysis of airborne pollen grains in Kirklareli. Turkish Journal of Botany. 35: 57-65.

Faegri, K., Iversen, J. (1964). Textbook of Pollen Analysis. II Edition, Munksgaard, Copenhagen, Denmark.

Giesecke, T., Fontana, S.L., Van Der Knaap, W.O., Pardoe, H.S., Pidek, I.A. (2010). From early pollen trapping experiments to the Pollen Monitoring Programme. Vegetation History and Archaeobotany. 19 (4): 247-258.

Güner, A., Özhatay, N., Ekim, T., Başer, K.H.C. (2000). Flora of Turkey and The East Aegean Islands. Vol. 11, Supplement II, at the University Press, Edinburgh.

Hesse, M., Zetter, R., Halbritter, H., Weber, M., Buchner, R., Frosch-Radivo, A., Ulrich, S. (2009). Pollen Terminology an illustrated handbook. Austria, Springer Wien New York.

Hicks, S. (1994). Present and past pollen records of Lapland forests. Review of Palaeobotany \& Palynology. 82: 17-35.

Hicks, S. (2001). The use of annual arboreal pollen deposition values for delimiting tree-lines in the landscape and exploring models of pollen dispersal. Review of Palaeobotany and Palynology. 117: 1-29.

Hicks, S., Hyvärinen, V.P. (1986). Sampling modern pollen deposition by means of 'Tauber traps': some considerations. Pollen et Spores. 28: 219242.

Hicks, S., Ammann, B., Latalowa, M., Pardoe, H., Tinsley, H. (1996). European Pollen Monitoring Programme: Project Description and Guidelines. University of Oulu, $28 \mathrm{pp}$.

Hyde, H. A., Adams, K. F. (1958). An Atlas of Airborne Pollen Grains. Macmillan Company, London.
Iwanami, Y., Sasakuma, T., Yamada, Y. (1988). Pollen: Illustrations and Scanning Electronmicrographs. Kodonsha-Tokyo.

Ince, A., Pehlivan, S. (1990). Serik (Antalya) havasının allerjenik polenleri ile ilgili bir araştırma. Gaz̧i Tip Dergisi. 1: 35-40.

İnceoğlu, Ö., Pınar, N.M., Şakıyan, N., Sorkun, K. (1994). Airborne pollen concentration in Ankara-Turkey 19901993. Grana. 33: 158-161.

Karlıoğlu, N., Akkemik, Ü. (2012). Modern pollen influx in the Research Forest of Istanbul University Forestry Faculty during September 2007- August 2009, Journal of the Faculty of Forestry, Istanbul University, 62 (2):145-158.

Kavgacı, A. (2007). Demirköy-İğneada Longoz Ormanları ve Çevresinin Bitki Toplumları ve Kuruluş Özellikleri. Doktora Tezi, İ.Ü. Fen Bilimleri Enstitüsü, 215 s.

Kaya, Z., Aras, A. (2004). Airborne pollen calendar of BartınTurkey. Aerobiologia. 20 (1): 63-67.

Moore, P., Webb, J. A., Collinson, M. E. (1991). Pollen Analysis. 2nd Edition, Blackwell, Oxford, 216 pp.

Öneş, Ü., Sapan, N., Malyer, H., Güler, N., Bıçakçı, A., Tamay, Z., Tatlidil, S. (2008). İstanbul İlinin Allerjik Polen Takvimi. TÜBİTAK SBAG Proje No:102S021.

Özhatay, N., Byfield, A., Atay, S. (2005). Türkiye'nin 122 Önemli Bitki Alanı, Doğal Hayatı Koruma Vakfı (WWF Türkiye) Yayını, İstanbul.

Pamay, B. (1967). Demirköy-Ĭgneada Longos Ormanlarmin Silvikültürel Analiz̨i ve Verimli Hale Getirilmesi İ̧in Alnması Gereken Silvikültürel Tedbirler Üzerine Araștırmalar. Orman Genel Müdürlüğü Yayınları, İstanbul, No. 451/43, 174 s.

Pehlivan, S., Bütev, F. (1994). Aksaray ili atmosferindeki polenlerin araştırılması. Journal of the Institute of Science and Technology of Gazi University. 7: 143-151.

Pidek, I.A. (2004). Preliminary results of pollen trapping in the region of the Roztocze National Park (SE Poland). Annales Univ. M. Curie-Sklodowska sect. B. 49:143-159.

Pidek, I.A. (2007). Nine-year record of Alnus pollen deposition in the Roztocze Region (SE Poland) with relation to vegetation data. Acta Agrobotanica. 60 (2): 57 64.

Pidek, I.A., Svitavska-Svobodova, H., Van Der Knaap, W.O., Noryskiewicz, A.M., Filbrandt-Czaja, A., Noryskiewicz, B., Latalowa, M., Zimny, M., Swieta-Musznicka, J., Bozilova, E., Tonkov, S., Filipova-Marinova, M., Poska, A., Giesecke, T., Gikov, A. (2010). Variation in annual pollen accumulation rates of Fagus along a N-S transect in Europe based on pollen traps. Vegetation History and Archaeobotany. 19: 259-270. 
Stockmarr, J. (1971). Tablets with spores used in absolute pollen analysis. Pollen et Spores. 13: 615-621.

Sugita, S., Gaillard, M.J., Broström, A. (1999). Landscape openness and pollen records: A simulation approach. The Holocene. 9 (4): 409-421.

Suszka, B. (1980). Rozmnazanie generatywne (Generative propagartion), Bialobok S. (red). Olsze/Alder (Alnus Mill.), Nasze drzewa lesne. 8.PWN. Warszawa-Poznan, 99-144.

Tauber, H. (1974). A static non-overload pollen collector. New Phytologist. 73: 359-369.

Tecimen, H.B., Kavgac1, A., (2010). Comparison of soil and forest floor properties of floodplain and surrounding forests in Igneada- Turkey, Journal of Environmental Biology, 31, 129134.

Tonkov, S., Hicks, S., Bozilova, E., Atanassova, J. (2001). Pollen monitoring in the Central Rila Mountains, Southwestern Bulgaria: case studies from pollen traps, surface samples for the period 1994-1999. Review of Palaeobotany and Palynology. 117: 167-182.

Van Der Knaap, W.O., Van Leeuwen, J.F.N., Ammann, B. (2001). Seven years of annual pollen influx at the forest limit in the Swiss Alps studied by pollen traps: relations to vegetation and climate. Review of Palaeobotany \& Palynology. 117: 31-52.

Wodehouse, R. P. (1935). Pollen Grains. Hafner Publishing Company, New York, 574 pp.

Submitted: 12.01 .2015

Accepted: 13.01.2015 